\title{
Analisis Usaha Pemberian Bakteri Asam Laktat (BAL) pada Ayam Pedaging terhadap Persentase Berat Karkas
}

\author{
Economic Analysis of Supplementing Lactic Acid Bacteria (LAB) in Broiler on Percentage of \\ Carcass Weight
}

\section{R. F. Syam¹, K. Soepranianondo², W. P. Lokapirnasari², Soeharsono ${ }^{3}$, S. Hidanah², Ardianto}

${ }^{1}$ Program Magister, Agribisnis Veteriner, Fakultas Kedokteran Hewan, Universitas Airlangga

${ }^{2}$ Departemen Peternakan, Fakultas Kedokteran Hewan, Universitas Airlangga

${ }^{3}$ Departemen Anatomi, Fakultas Kedokteran Hewan, Universitas Airlangga

${ }^{4}$ Departemen Akuntansi, Fakultas Ekonomi dan Bisnis, Universitas Airlangga

Kampus C, Jl. Mulyorejo, Kota Surabaya, Jawa Timur, Indonesia

Office Phone. +62 31 5992785, 5993016; Fax. +62 315993015

Corresponding Author: ranafitrianisyam12@yahoo.com

\begin{abstract}
Livestock is an agricultural subsector that has an important role to complete increasing needs of animal protein. Bacteria, viruses, parasites, fungi, environment and nutritional deficiencies are the agent of susceptible attack in poultry. Antibiotic is one of the method to treatment and prevention of disease, but antibiotics that overuse can cause antibiotic residues. The purpose of this study was to know the economic analysis in broiler supplemented with lactic acid bacteria to increase percentage of carcass weight. About 300 DOC (Day Old Chicken) were completely randomized into three treatments, each treatment consisted of 100 heads. The treatments were T0 (commercial feed and water without probiotic), T1 (commercial feed and water + LAB $10^{6} \mathrm{CFU} / \mathrm{ml}$ ), and T3 (commercial feed and water $+\mathrm{LAB} 10^{8} \mathrm{CFU} / \mathrm{ml}$ ). The results showed that $\mathrm{LAB}$ in water has not been able to increase percentage of carcass weight, but feasible to be practiced because still give profit.
\end{abstract}

Keyword: Economic analysis, LAB, broiler, carcass

\begin{abstract}
ABSTRAK
Peternakan merupakan subsektor pertanian yang memiliki peran penting dalam pemenuhan kebutuhan protein hewani yang semakin meningkat. Bakteri, virus, parasit, jamur, lingkungan dan kekurangan nutrisi merupakan penyebab rentannya peternakan ayam pedaging terserang penyakit. Penggunaan antibiotik merupakan salah satu cara pengobatan dan pencegahan penyakit, namun pemberian antibiotik yang tidak tepat dosis dapat menimbulkan residu antibiotik. Tujuan penelitian ini adalah untuk mengetahui analisis usaha ayam pedaging yang diberi bakteri asam laktat terhadap peningkatan persentase berat karkas. Terdiri dari 300 ekor DOC yang diacak kedalam tiga kelompok perlakuan, masing-masing terdiri dari 100 ekor. Perlakuan terdiri dari P0 (Pakan komersial dan air minum), P1 (Pakan komersial dan air minum + BAL $106 \mathrm{CFU} / \mathrm{ml}$ ), dan P3 (pakan komersial dan air minum + BAL $108 \mathrm{CFU} / \mathrm{ml}$ ). Hasil penelitian menunjukkan bahwa pemberian BAL pada air minum belum mampu meningkatkan persentase berat karkas dan menurunkan persentase lemak abdominal, namun layak untuk dilakukan karena masih memberikan keuntungan.
\end{abstract}

Kata kunci: Analisis usaha, BAL, ayam pedaging, karkas, lemak abdominal

\section{PENDAHULUAN}

Peternakan merupakan subsektor pertanian yang memiliki peran penting dalam pemenuhan kebutuhan protein hewani yang semakin meningkat (Pardede, 2015). Bakteri, virus, parasit, jamur, lingkungan dan kekurangan nutrisi merupakan penyebab rentannya peternakan ayam pedaging terserang penyakit (Tamaluddin, 2012).

Pemberian antibiotik merupakan salah satu cara dalam pencegahan dan pengobatan penyakit yang dapat digunakan sebagai imbuhan pakan (feed additive) untuk meningkatkan produksi, meningkatkan efisiensi pakan, dan memacu pertumbuhan (Bahri et al., 2005). Pemberian antibiotik 
yang tidak tepat dosis dapat menimbulkan residu antibiotik (Etikaningrum dan Iwantoro, 2017).

Probiotik merupakan salah satu produk alternatif yang diberikan untuk memperbaiki laju pertumbuhan, kesehatan ternak, efisiensi dan konversi ransum karena mengandung mikroba hidup non patogen (Zurmiati et al., 2014). Probiotik terdiri dari bakteri asam laktat yang memiliki kemampuan memelihara keseimbangan mikroflora normal usus dan menghambat bakteri patogen (Salarmoni dan Fooladi, 2011).

Lactobaccillus sp., Pediococcus dan Bifidobacterium merupakan golongan bakteri asam laktat dari flora normal yang sering digunakan sebagai probiotik (Yuniastuti, 2014). Lactobacillus adalah probiotik yang dapat meningkatan kesehatan host dengan meningkatkan keseimbangan mikroba dan imunitas usus (Shen et al., 2014). Bifidobacterium bermanfaat melindungi mukosa usus terhadap mikroba patogen, meningkatkan pertahanan usus, sintesis vitamin yang larut dalam air, pencernaan oligosakarida dan polisakarida, menekan produksi yang berpotensi beracun dan metabolisme karsinogenik melalui modulasi respon imun (Quigley, 2017). Pediococcus mampu menghambat pertumbuhan bakteri karena adanya bakteriosin (pediosin) sebagai senyawa antimikroba (Soomro et al., 2002).

Pemberian kombinasi bakteri asam laktat melalui air minum merupakan salah satu alternatif untuk meningkatkan Total Digestible Nutrien (TDN) dan metabolisme energi (ME) (Ikasari, 2017). Berdasarkan hal tersebut diharapkan dalam penambahan bakteri asam laktat dapat meningkatkan persentase berat karkas pada ayam pedaging. Melalui analisis usaha dengan parameter biaya total, penerimaan, laba rugi dan Contribution Margin, akan diketahui apakah pemberian bakteri asam laktat pada air minum ayam pedaging memberikan keuntungan atau tidak. Penelitian ini bertujuan untuk mengetahui analisis usaha pertenakan ayam pedaging yang menggunakan bakteri asam laktat kombinasi dari Lactobacillus casei, Lactobacillus plantarum, Lactobacillus fermentum, Lactobacillus acidophilus, Pediococcus dan Bifidobacterium terhadap persentase berat karkas.

\section{MATERI DAN METODE}

Bahan-bahan yang digunakan pada penelitian ini adalah enam bakteri asam laktat (kombinasi dari Lactobacillus casei, Lactobacillus plantarum, Lactobacillus fermentum, Lactobacillus acidophilus, Pediococcus dan Bifidobacterium) dengan konsentrasi yang berbeda antar perlakuan yaitu $10^{6} \mathrm{CFU} / \mathrm{ml}$ dan $10^{8} \mathrm{CFU} / \mathrm{ml}$, dextrose $10 \mathrm{~g}$ dalam 1 liter air, pakan komersial CP 511 (mengandung protein kasar 21-23\%, lemak 5-8\%, serat kasar 3-5\%, abu 4-7\%), desinfektan menggunakan campuran forcent $500 \mathrm{~g}$ dalam formalin 1 liter. Hewan coba yang digunakan yaitu ayam pedaging strain Cobb mulai umur DOC sebanyak 30 ekor yang berasal dari breeding Missouri Bandung.

Pengumpulan data berat karkas dilakukan setelah penyembelihan, pencabutan bulu, pengeluaran saluran pencernaan dan organ dalam, dan pemisahan kepala dan ceker dari bagian tubuh. Perhitungan persentase berat karkas menggunakan rumus:

Berat Karkas $(\%)=\frac{\text { BeratKarkas }}{\text { BeratHidup }} \times 100 \%$

Analisis data hasil eksperimen yang didapat diolah menggunakan Microsoft Excel kemudian dianalisis statistik menggunakan Multivariate Analysis of Variance (MANOVA). Apabila diperoleh hasil yang berbeda atau berbeda sangat nyata maka akan dilanjutkan dengan Uji Jarak Berganda Duncan (Kusriningrum, 2008). Analisis statistik menggunakan program SPSS for Windows 23.0. Data analisis usaha dan finansial yang dihitung menggunakan rumus:

Biaya produksi

Biaya total = biaya tetap + biaya variabel 
Penerimaan

Penerimaan $=$ harga/unit $\mathrm{x}$ total produksi

Laba rugi

Laba rugi $=$ penerimaan - biaya total

Kontribusi margin

Kontribusi margin $=$ penjualan - biaya variabel

\section{HASIL DAN PEMBAHASAN}

\section{Persentase Berat Karkas}

Hasil dari MANOVA pemberian bakteri asam laktat pada air minum ayam pedaging tidak menunjukkan adanya perbedaan yang nyata $(\mathrm{p}>0,05)$ pada persentase berat karkas. Hasil persentase berat karkas dapat dilihat pada Tabel 1. Hal tersebut menunjukkan bahwa pemberian bakteri asam laktat dalam air minum dengan dosis $1 \mathrm{ml} /$ liter tidak mampu mengubah persentase berat karkas secara signifikan. Pemberian bakteri asam laktat pada pakan memiliki perolehan peningkatan rata-rata lebih tinggi dibandingkan pemberian pada air minum (Olnood et al., 2015). Patterson dan Burkholder (2003), mengemukakan bahwa kemanjuran probiotik dipengaruhi oleh metode pengaplikasian, tingkat pemberian, pakan basal, jenis galur ayam dan konsentrasi probiotik. Berdasarkan hasil penelitian yang dilakukan Atela et al. (2018) yaitu pemberian 5,0 $\mathrm{mL} / \mathrm{L}$ pada ayam jantan berumur 9 minggu menghasilkan efisiensi konversi pakan yang lebih tinggi yang menandakan bahwa probiotik dengan dosis yang lebih tinggi dapat mempengaruhi efisiensi konversi pakan.

Tabel 1. Nilai rata-rata dan simpang baku persentase karkas ayam pedaging

\begin{tabular}{cc}
\hline Perlakuan & $\begin{array}{c}\text { Persentase berat karkas } \\
(\%) \pm \text { SD }\end{array}$ \\
\hline P0 & $75,41 \pm 2,44$ \\
P1 & $72,96 \pm 2,07$ \\
P2 & $74,14 \pm 2,39$ \\
\hline
\end{tabular}

Menurut Akhadiarto (2010), strain, berat hidup, kualitas dan kuantitas pakan dan berat non karkas merupakan faktor-faktor yang dapat mempengaruhi berat karkas. Salah satu faktor yang mempengaruhi hasil peneliatian ini adalah pakan karena disetiap fase pertumbuhan tidak dilakukan perubahan pakan sesuai kebutuhan ayam pedaging disetiap fase pertumbuhannya. Kualitas pakan yang diberikan sangat menentukan kandungan dan ketersediaan nutrisinya dalam memenuhi kebutuhan ayam pedaging selama masa pemeliharaan (Hafsan et al., 2018). Hasil penelitian $\mathrm{Li}$ et al. (2014), membuktikan bahwa pemberian pakan pada ayam pedaging dengan protein dan energi yang sama tidak memberikan efek pada berat karkas. Olnood et al. (2015), mengungkapkan bahwa pemberian bakteri asam laktat berpotensi meningkatkan penyerapan nutrisi pada ayam pedaging, dapat meningkatkan kinerja pertumbuhan dan efisiensi pakan.

Rata-rata persentase berat karkas yang dihasilkan pada penelitian ini adalah $74,17 \%$ sesuai yang diungkapkan (Tarigan $e t$ al., 2013), bahwa persentase karkas ayam pedaging bervariasi sekitar $65-75 \%$ dari berat badan. Persentase karkas sangat dipengaruhi oleh berat potong, berat karkas, berat lemak abdominal dan kesehatan ternak. Persentase karkas yang tinggi disebabkan oleh berat karkas yang diperoleh lebih besar karena ditunjang perdagingan otot paha dan dada yang lebih baik berhubungan dengan jenis kelamin, umur dan berat badan (Jaelani et al., 2015).

\section{Biaya tetap}

Biaya tetap adalah biaya yang tetap konstan, secara total terlepas dari perubahan tingkat aktivitas (Garrison et al., 2015). Biaya tetap yang dikeluarkan adalah penyusutan kandang, penyusutan peralatan dan biaya tenaga kerja. Biaya penyusutan kandang dan penyusutan peralatan dihitung menggunakan rumus depresiasi yaitu biaya investasi dibagi umur penggunaan (ekonomis). Biaya tetap dapat dilihat pada Tabel 2. 
Tabel 2. Biaya tetap

\begin{tabular}{lrrr}
\hline \multicolumn{1}{c}{ Deskripsi } & \multicolumn{1}{c}{ P0 } & \multicolumn{1}{c}{ P1 } & \multicolumn{1}{c}{ P2 } \\
\hline Penyusutan kandang (Rp) & $277.777,78$ & $277.777,78$ & $277.777,78$ \\
Penyusutan feeder (Rp) & $3.333,33$ & $3.333,33$ & $3.333,33$ \\
Penyusutan drinken (Rp) & 2.500 & 2.500 & 2.500 \\
Tenaga kerja (Rp) & $166.666,67$ & $166.666,67$ & $166,666,67$ \\
\hline \multicolumn{1}{c}{ Total (Rp) } & $450.277,78$ & $450.277,78$ & $450.277,78$ \\
\hline
\end{tabular}

\section{Biaya Variabel}

Biaya variabel adalah variasi total biaya yang berbanding lurus dengan perubahan tingkat aktivitas. Biaya langsung yang digunakan selama suatu periode akan bervariasi secara total dalam bentuk langsung dengan jumlah unit yang diproduksi
(Garrison et al., 2015). Biaya variabel terdiri dari biaya DOC, pakan, air minum, listrik, sekam, formalin, dextrose, formalin, forcent, perlengkapan penelitian dan probiotik untuk perlakuan. Biaya variabel dapat dilihat pada Tabel 3.

Tabel 3. Biaya variabel

\begin{tabular}{lrrr}
\hline \multicolumn{1}{c}{ Deskripsi } & \multicolumn{1}{c}{ P0 } & P1 & \multicolumn{1}{c}{ P2 } \\
\hline DOC (Rp) & 360.000 & 360.000 & 360.000 \\
Pakan (Rp) & 645.883 & 645.883 & 645.883 \\
Air minum (Rp) & 100.000 & 100.000 & 100.000 \\
Dextrose (Rp) & 55.000 & 55.000 & 55.000 \\
Listrik (Rp) & 66.667 & 66.667 & 66.667 \\
Sekam (Rp) & 50.000 & 50.000 & 50.000 \\
Formalin (Rp) & 60.000 & 60.000 & 60.000 \\
Forcent (Rp) & 500.000 & 500.000 & 500.000 \\
Perlengkapan (Rp) & 33.333 & 33.333 & 33.333 \\
Total (Rp) & 1.870 .883 & 1.870 .883 & 1.870 .883 \\
Bakteri Asam Laktat & 0 & 50.000 & 75.000 \\
\multicolumn{1}{c}{ Total (Rp) } & 1.870 .883 & 1.920 .883 & 1.945 .883 \\
\hline
\end{tabular}

\section{Penerimaan}

Penerimaan adalah jumlah yang diperoleh dari penjualan sejumlah pengeluaran yang dihasilkan oleh perusahaan atau produsen (Nurdin, 2010). Arus penerimaan yang diperoleh berasal dari hasil penjualan per kilogram karkas ayam pedaging. Hasil penerimaan dari penjualan karkas tertinggi pada P0 adalah Rp 2.638.692,00 karena total produksi yang dihasilkan yaitu $146,594 \mathrm{~kg}$ dan terendah pada P1 adalah Rp 2.451.528,00 dengan berat total $136,196 \mathrm{~kg}$. Rincian penerimaan dapat dilihat pada Tabel 4.

Tabel 4. Penerimaan penjualan karkas

\begin{tabular}{cccc}
\hline \multirow{2}{*}{ Harga/unit $(\mathrm{Rp} / \mathrm{kg})$} & \multicolumn{2}{c}{ Total Produksi } & \multirow{2}{*}{ Penerimaan $(\mathrm{Rp})$} \\
\cline { 2 - 3 } & Perlakuan & Berat $(\mathrm{kg})$ & 2.638 .692 \\
18.000 & P0 & 146,594 & 2.451 .528 \\
18.000 & P1 & 136,196 & 2.556 .162 \\
18.000 & P2 & 142,009 & \\
\hline
\end{tabular}

\section{Laba- Rugi}

Laba merupakan target utama perusahaan (Dewi et al., 2017). Laba tertinggi terdapat pada $\mathrm{P0}$ adalah $\mathrm{Rp}$
317.531,22 karena tingginya berat produksi yang dihasilkan dan tidak adanya beban biaya BAL. Laba terendah pada P1 adalah Rp 80.367,22 yang dipengaruhi oleh 
sedikitnya berat produksi yang dihasilkan

dapat dilihat pada Tabel 5.

dan adanya beban biaya BAL. Rincian laba

Tabel 5. Laba penjualan karkas

\begin{tabular}{cccc}
\hline Perlakuan & Penerimaan $(\mathrm{Rp})$ & Biaya Total $(\mathrm{Rp})$ & Laba $(\mathrm{Rp})$ \\
\hline P0 & 2.638 .692 & $2.321 .160,78$ & $317.531,22$ \\
P1 & 2.451 .528 & $2.371 .160,78$ & $80.367,22$ \\
P2 & 2.556 .162 & $2.396 .160,78$ & $160.001,22$ \\
\hline
\end{tabular}

\section{Analisis Usaha}

\section{Kontribusi margin}

Contribution margin merupakan selisih antara semua biaya variable dengan pendapatan penjualan. Kontribusi margin digunakan untuk menutupi biaya tetap dan sisanya akan menjadi laba (Yahya, 2018). Kontribusi margin dapat menutupi total biaya tetap yang dikeluarkan dapat dilihat pada Tabel 6.

Tabel 6. Contribution margin

\begin{tabular}{cccc}
\hline Perlakuan & Penerimaan $(\mathrm{Rp})$ & Biaya Variabel $(\mathrm{Rp})$ & Jumlah $(\mathrm{Rp})$ \\
\hline P0 & 2.638 .692 & 1.870 .883 & 767.809 \\
P1 & 2.451 .528 & 1.920 .883 & 530.645 \\
P2 & 2.556 .162 & 1.945 .883 & 610.279 \\
\hline
\end{tabular}

\section{KESIMPULAN}

Penambahan bakteri asam laktat pada air minum belum mampu meningkatkan persentase berat karkas ayam pedaging, namun analisis usaha berdasarkan Contribution Margin dapat menutupi keseluruhan biaya tetap sehingga masih layak untuk dilakukan. Perlu dilakukan uji pemberian BAL dengan metode lain seperti melalui pakan atau tetes, pembemberian harus dilakukan dengan cara dan dosis yang tepat, dan dilakukan pemuasaan sebelum pemotongan.

\section{DAFTAR PUSTAKA}

Akhadiarto, S. 2010. Pengaruh Pemberian Probiotik Temban, Biovet dan Biolacta terhadap Persentase Karkas, Bobot Lemak Abdomen dan Organ Dalam Ayam Broiler. Jurnal Sains dan Teknologi Indonesia. 12 (1): 5359 .

Atela, J.A., V. Mlambo and C.M. Mnisi. 2018. A multi-strain Probiotic Administered Via Drinking Water
Enhances Feed Conversion Efficiency and Meat Quality Traits in Indigenous Chickens. Animal Nutrition. 30: 1-6.

Bahri, S., E. Masbulan, A. Kusumaningsih. 2005. Proses Produksi sebagai Faktor Penting dalam Menghasilkan Produk Ternak yang Aman untuk Manusia. Jurnal Litbang Pertanian.24 (1): 2735 .

Dewi, D.R.R., S. B. Wibowo dan N. W. Sulistyowati. 2017. Analisis Hubungan Margin Kontribusi sebagai Alat Bantu Perencanaan Laba pada Industri Gamelan Margo Laras Kauman Magetan Periode 2014-2016. The 9th FIPA: Forum Ilmiah Pendidikan Akuntansi. Universitas PGRI. Madiun.

Etikaningrum dan S. Iwantoro. 2017. Kajian Residu Antibiotika pada Produk Ternak Unggas di Indonesia. Jurnal Ilmu Produksi dan Teknologi Hasil Peternakan. 5(1): 29-33.

Garrison, R.H., E.W. Noreen, P.C. Brewer, N.S. Cheng and K.C.K. Yuen. 2015. 
Managerial Accounting. Second Edition. MC Graw Hill Education. 2 Penn Plaza. New York.

Hafsan, G. Bayu, Ar. S. Hidayat, L. Agustina, A. Natsir dan A. Ahmad. 2018. Bobot Karkas dan Persentase Organ Dalam Broiler dengan Suplementasi Fitase dari Bukholderia sp. Strain HF.7. Prosiding Seminar Nasional Biologi dan Pembelajarannya. Inovasi Pembelajaran dan Penelitian Biologi Berbasis Potensi Alam. 479-484.

Ikasari, A. T. 2017. Pengaruh Pemberian Probiotik terhadap Persentase Karkas dan Lemak Karkas pada Broiler. Fakultas Sains dan Teknologi. Universitas Islam Negeri Alauddin. Makassar. Repository.uinalauddin.ac.id. 20 April 2019.

Jaelani, A., A. Gunawan dan S. Syaifuddin. 2015. Pengaruh Penambahan Probiotik Storbio Dalam Ransum Terhadap Bobot Potong, Persentase Karkas dan Persentase Lemak Abdominal Ayam Broiler. Ziraa'ah. 39 (2): 85-94.

Kusriningrum, R.S. 2008. Perancangan Percobaan. Airlangga University Press. Surabaya.

Li, C.-Y., Lu, J.-J., Wu, C.-P., and Lien, T.F. 2014. Effects of Probiotics and Bremelain Fermented Soybean Meal Replacing Fish Meal on Growth Performance, Nutrient Retention and Carcass Traits of Broiler. Livestock Science. 163: 94-101.

Nurdin, H.S. 2010. Analisis Penerimaan Bersih Usaha Tanaman pada Petani Nenas di Desa Palaran Samarinda. Jurnal Eksis. 6 (1): 1267-1266.

Olnood, C.G., S.S.M. Beski., P.A. Iji and M. Choct. 2015. Delivery Routes for Probiotics: Effects on Broiler Performance Intestinal Morphology and Gut Microflora. Animal Nutrition 1: 192-202.

Pardede, S. 2015. Analisis Biaya dan Keuntungan Usaha Peternakan Babi Rakyat di Desa Cigugur, Kecamatan Cigugur, Kabupaten Kuningan Jawa Barat. Universitas Padjajaran. Bandung.

Patterson, J.A. and Burkholder, K.M. 2003. Application of Prebiotics and Probiotics in Poutry Production. Poultry Science. 82: 627-631.

Salam, S., A. Fatahilah, D. Sunarti dan Isroli. 2013. Berat Karkas dan Lemak Abdominal Ayam Broiler yang diberi Tepung Jintan HItam (Nigella sativa) dalam Ransum selama Musim Panas. Sains Peternakan. 11 (2): 84-90.

Salarmoni, M. and M.H. Fooladi. 2011. Efficacy of Lactobacillus acidophilus as Probiotic to Improve Broiler Chicks Performance. J. Agr. Sci. Tech, 13: 165-172.

Shen, X., and Yi, Xueqin Ni, D. Zeng, B. Jing, M. Lei, Z. Bian, y. Zeng Tao Li and J. Xin. 2014. Effects of Lactobacillus plantarum on Production Performance, Immune Characterisctics, Antioxidant Status and Intestinal Microflora or Bursin Ummunized Broilers. Canadian Journal of Microbiology. 60 (4): 193202.

Soomro, A.H., T. Masud and K. Anwaar. 2002. Role of Lactic Acid Bacteria (LAB) in Food Preservation and Human Health a Review. Pakistan Journal of Nutrition. 1(1): 20-24.

Tamalluddin, F. 2012. Ayam Broiler, 22 Hari Panen Lebih Untung. Penebar Swadaya. Jakarta.

Tarigan, R., O. Sjofjan dan I. H. Djunaidi. 2013. Pengaruh Penambahan Probiotik Selulolitik (Cellulomonas 
sp) dalam Pakan terhadap Kualitas Karkas, Lemak Abdominal dan Berat Organ Dalam Ayam Pedaging. Universitas Brawijaya. Malang.

Quigley, E.M.M. 2017. Bifidobacteria as Probiotic Organisms: An Introduction. The Microbiota in Gastrointestinal Pathophysiology. Chapter 12. United States.

Yahya, D.B. 2018. Penerapan Cost Volume Profit Main Product dan Byproduct Sebagai Alat Bantu Perencanaan Laba pada Peternakan Ayam Slorok Farm. Fakultas Ekonomi. Universitas Negeri Surabaya. Surabaya. Jurnalmahasiswa.unesa.ac.id. $\quad 19$ April 2019.

Yuniastuti, A. 2014. Buku Monograf: Probiotik (Dalam Perpektif Kesehatan). Unnes Press. Semarang.

Zurmiati, M.E.M, M.H. Abbas dan Wizna. 2014. Aplikasi Probiotik Untuk Ternak Itik. Jurnal Peternakan Indonesia. 16 (2): 134-144. 